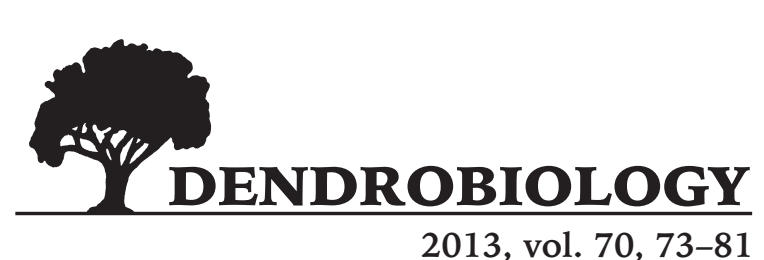

http://dx.doi.org/10.12657/denbio.070.008

\title{
Oliver Gailing
}

\section{Differences in growth, survival and phenology in Quercus rubra and Q. ellipsoidalis seedlings}

\author{
Received: 22 November 2012; Accepted 26 March 2013
}

\begin{abstract}
Related oak species with different ecological requirements often hybridize where they co-occur. Even though interspecific gene flow is considered to be common in closely related oaks, species identity in sympatric oak species with different local adaptations is generally maintained with a low number of hybrids and introgressive forms in the adult tree generation. Quercus rubra and Q. ellipsoidalis offer a good model to study characters that are related to different local adaptations and reproductive isolation of the species. Both species are interfertile, but grow in different micro-environments with Q. ellipsoidalis as the most drought tolerant red oak species occurring often on very dry sites. In an earlier study, genetic assignment analysis at 15 highly variable microsatellite markers revealed a low number of hybrids (0-2\%) and introgressive forms $(0-4 \%)$ in neighboring Q. ellipsoidalis and Q. rubra populations in both the adult tree and seedling generation. In the present study, pronounced differences in growth and survival, the timing of bud burst and leaf senescence between seedlings of both species in a common garden experiment suggested reproductive isolation between species and genetic differences in fitness-related traits. Future studies should focus on the analysis of fitness traits in parental environments using reciprocal transplant studies.
\end{abstract}

Additional keywords: Common gardens, local adaptation, hybridization, red oaks

Address: O. Gailing, Michigan Technological University, 1400 Townsend Drive, 49931 Houghton, MI, United States, ogailing@mtu.edu

\section{Introduction}

Oaks are economically and ecologically important species in temperate regions of the world including North America (Aldrich and Cavender-Bares 2011). Climate change is expected to result in a northward migration of drought adapted oak species in the eastern United States (Woodall et al. 2009) resulting in new contact zones between species. Thus hybridization between interfertile oak species with different adaptations to drought is expected to be more frequent in the future as the result of secondary contact between formerly isolated populations.

Hybridization in plants is considered to play an important role in adaptive evolution, the transfer of adaptive traits among species (Arnold and Martin 2010) and affects biodiversity of associated insect and fungal communities (Whitham et al. 1999). Oaks show a propensity to hybridize where distribution ranges of the species overlap (e.g. Curtu et al. 2009; Hokanson et al. 1993; Lepais et al. 2009; Petit et al. 2003; Zeng et al. 2010). Thus, ecologically divergent oak species often occur in one stand or region, but in different micro-environments. Despite interspecific gene flow, most adult trees can be assigned to a species based on morphological and/or genetic characters suggesting a role of environmental selection in maintaining species identity (Curtu et al. 2007; Dodd and Afzal-Rafii 2004). Likewise pre-zygotic mechanisms (differences in flowering time, crossing incom- 
patibility, availability of conspecific and heterospecific pollen) can contribute to the reproductive isolation of oak species, and the relative importance of different isolation mechanisms in interfertile oak species is strongly dependent on environmental conditions (Lepais and Gerber 2011; Lepais et al. 2009).

The North American red oak species Q. rubra and Q. ellipsoidalis offer a good model to study aspects of pre- and post-zygotic isolation between interfertile oak species with different local adaptations to drought. The occurrence of morphologically intermediate individuals and low differentiation at isozyme markers suggested frequent interspecific hybridization at their northern distribution limit (Hokanson et al. 1993; Jensen et al. 1993). At their southern distribution edge the number of interspecific hybrids as inferred from morphological and genetic assignment analyses appears to be less frequent (Hipp and Weber 2008; Andrew Hipp, personal communication). Genetic assignment analyses using highly variable microsatellite markers suggested low levels of effective gene flow between $Q$. rubra and Q. ellipsoidalis in a region on the Upper Peninsula of Michigan where both species occur in gene flow distance on neighboring sites (Gailing et al. 2012; Lind and Gailing 2013). Thus, the number of putative hybrids or introgressive forms was very low in the adult $(0-4 \%)$ as well as in the seedling generation $(0-3 \%$, one and a half year old seedlings) (Lind and Gailing 2013) suggesting either selection against hybrid seeds and young seedlings or pre-zygotic isolation between species.

Both species are the only red oak species native to the sampling area on the Upper Peninsula of Michigan, thus interspecific gene flow with other oak species can be excluded. Q. rubra is by far the most frequent species and grows on mesic slopes and well-drained uplands, while Q. ellipsoidalis as the most drought tolerant red oak species (Abrams 1988, 1990 ) is reported only on very dry sites (Barnes and Wagner Jr. 2004; Nixon 1997). Q. ellipsoidalis shows specific morphological (e.g. small dissected leaves) and physiological adaptations (maintenance of high photosynthesis rate under drought conditions) to drought (Abrams 1990). Additionally, Q. ellipsoidalis is distinguished from $Q$. rubra by its shrubby growth habit, by smaller ellipsoid to round acorns and different cup characteristics (Barnes and Wagner Jr. 2004; Hipp and Weber 2008; Nixon 1997). Pronounced differences in growth habit, leaf shape and size, and seed production between neighboring populations of both species on contrasting sites (dry/mesic) suggested different local adaptations of the species or phenotypically plastic responses to different micro-environments (Gailing et al. 2012).

In long-lived forest trees like oaks the highest viability selection is observed at the early seedling stage (Müller-Starck 1985). Thus, the aim of the present study is to analyze Q. rubra and Q. ellipsoidalis seedlings from different regions at fitness-related traits (survival and growth) and at phenological traits such as bud burst as a proxy for flowering time (Chesnoiu et al. 2009) in a common environment under non-drought stress conditions, in order to detect genetic differences in trait expression. Pre- and post-zygotic reproductive barriers between species such as differences in the timing of bud burst and in growth and survival are hypothesized. This study will yield first insights into mechanisms of reproductive isolation between both species. Reciprocal transplant experiments and scoring of bud burst and flowering time under field conditions are necessary to better understand isolation mechanisms and different local adaptations of the species.

\section{Material and methods}

\section{Adult tree populations}

A total of 1958 seeds were collected in fall 2009 from four locations for $Q$. rubra and from one location for Q. ellipsoidalis, 799 of which germinated and were used in the seedling trial (Table 1). Q. rubra populations were located in more mesic environments in closed forests while the Q. ellipsoidalis population grew in an open savanna characterized by scattered $Q$. ellipsoidalis trees in a forest type characterized as Pine Barrens (Albert and Comer 2008). Among 11 populations that had between analyzed so far on the Upper Peninsula of Michigan, only two populations were identified as $Q$. ellipsoidalis based on genetic and leaf morphological assignment (Gailing et al. 2012; Lind and Gailing 2013). Since 2009 seeds have only been produced in two groups of trees (about 50 meters apart) in one Q. ellipsoidalis population (stand FC-E).

Pronounced differences in growth, seed production, growth habit and insect herbivory have been observed between neighboring adult stands of $Q$. rubra and Q. ellipsoidalis. Thus, Q. ellipsoidalis stand FC-E with the dominating species Q. ellipsoidalis and Pinus banksiana is characterized by shrubby trees (mean $\mathrm{DBH}=11.3 \mathrm{~cm}$ ) with an open canopy, low seed production since 2009 and high insect herbivory. The neighboring $Q$. rubra stand with dominating species Q. rubra, Acer saccharum and Tsuga canadensis is characterized by larger trees (mean DBH $=29.3 \mathrm{~cm}$ ), a closed canopy, low insect herbivory and abundant seed production since 2009. Since the Q. ellipsoidalis population grows on deep outwash sands and in open, less shaded stands, while Q. rubra occurs in a more mesic environment (Table 1), differences in growth and seed production might be due to differences in the micro-environment or due to genetic differences between species. Likewise, differences in growth habit were observed between $Q$. rubra popula- 


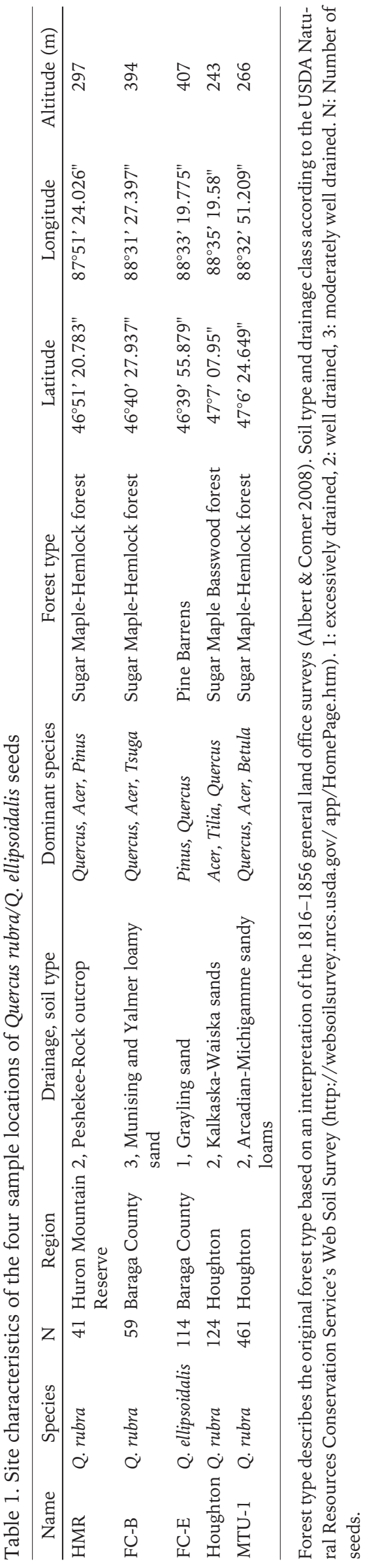


tions with population HMR on rock outcrops showing a shrubby growth habit more typical for $Q$. ellipsodidalis, while the other stands were characterized by large adult trees (Table 1).

\section{Seedling trial}

In order to separate between environmental and genetic effects on the phenotype a seedling common garden trial was established. The number of seedlings per sampled stand is given in Table 1. Seeds were sampled from the ground under adult trees for $Q$. rubra populations FC-B, HMR and MTU-1 that were characterized at microsatellite markers in earlier studies (Gailing et al. 2012; Lind and Gailing 2013). Q. rubra seeds for Houghton were collected from a single open-pollinated tree. For the Q. ellipsoidalis stand FC-E only a few trees had seeds, and seeds were collected from the ground under two groups of about 10 trees that were identified as $Q$. ellipsoidalis by genetic assignment analysis (Lind and Gailing 2013). After storage at $4^{\circ} \mathrm{C}$ for approximately four months, seeds were planted and grown in 0.5 gallon pots ( 1.89 liter $)$ filled with Sunshinel mix potting soil (Sun Grow Horticulture, Canada, containing 70-80\% Canadian Sphagnum peat moss, perlite, dolomite limestone, Gypsum and wetting agent) in a greenhouse at $20^{\circ} \mathrm{C}$ on February 5, 2010. A total of 799 germinating seeds were transferred to one gallon $(\sim 3.78$ liter $)$ pots filled with Sunshine1 mix potting soil on March 16, 2010 (Table 1). Pots were transferred outside the greenhouse on May 5, 2010 in a completely randomized design.

\section{Trait measurements}

Seed length and seed width were measured before planting. Plant height was measured on June 11, 2010 (height 6/11/10), on September 10, 2011 (height 9/10/11) and on November 19, 2012 (height $11 / 19 / 12$ ). Growth increment ( $\Delta$ height) was determined for each year and after two years as the difference between height $11 / 19 / 12$ and height 6/10/10. Leaf coloration/leaf fall was scored on a scale from 1 ( $>75 \%$ of leaves green) to 4 (all leaves red) and from 5 (leaves brown/red) to 7 (all leaves shed) on October 15, 2011 and September 26, 2012. Vegetative bud burst was scored in 2011 on a scale from 0 (terminal bud dormant) to 5 (terminal leaves completely unfolded) on May 5, May 15, May 23 and June 3. The highest variation in bud burst stages was calculated for May 23, and these data were used for further data analyses. After the transfer of the seedlings outside the greenhouse, survival was scored as the relative number of living plants on June 9, 2011 and on September 14, 2012.

\section{Data analyses}

In order to test for significant trait differences between seedling populations, one way analyses of vari- ance (ANOVA) were performed. In case of unequal variances significant differentiation was confirmed by the Kruskall-Wallis test that is not dependent on homogenous variances. Additionally, ANOVA was performed after adjusting for unequal sample sizes by randomly selecting seedlings from each population. Critical differences between groups and homogenous subsets were identified by the Least Significant Difference method. These analyses and other basic statistical analyses as the calculation of means and confidence intervals were done with the program WINSTAT (Fitch 2006). ANCOVA analyses using seed size as covariate were performed in SPSS ver. 20 (Inc 2002). Differentiation at quantitative traits was calculated as percentage of among population variation in a one way ANOVA. In order to compare genetic differentiation $\left(\mathrm{F}_{\mathrm{ST}}\right)$ among populations within species and between species at microsatellite markers (Lind and Gailing 2013; Sullivan et al. 2013) with morphological differentiation, quantitative trait differentiation was estimated for adjusted sample sizes

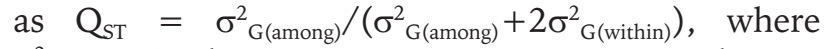
$\sigma_{\mathrm{G} \text { (among) }}^{2}$ is the genetic variance among populations

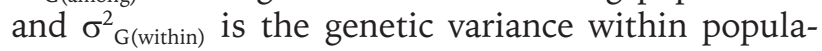
tions assuming that the traits are controlled by genes with additive gene effects (McKay and Latta 2002; Spitze 1993; Whitlock 2008).

\section{Results}

Significant differences between populations in seed length and seed width were found with FC-E showing the smallest and Houghton showing the largest seeds (data not shown). Seedling height in 2010 (height 6/11/10) was not significantly different for FC-B, FC-E, HMR and Houghton, but significantly higher for MTU-1 (Fig. 1). Seedling height in 2011, in 2012 and $\Delta$ height 2010-2011 was lowest for Q. ellipsoidalis seedlings from the sandy site FC-E followed by seedlings from the neighboring $Q$. rubra population FC-B on loamy sands (Figs. 1, 2).

Growth increment between 2010 and 2011 (Aheight 2010-2011) was significantly different among FC-E, FC-B and HMR/Houghton/MTU-1 seedlings. Differences among populations in seedling height remained significant when seed size was used as a covariate (data not shown). Growth increment between 2011 and 2012 ( $\Delta$ height 2011-2012) was minimal for all populations and not significant among populations (compare Fig. $1 \mathrm{~b}$ and 1c, $\Delta$ height 2011-2012 is not shown). Seedlings from Q. ellipsoidalis population FC-E flushed significantly later (i.e. showed an earlier bud burst stage on May 23, 2011) than seedlings from Q. rubra populations FC-B/Hougthon/MTU and HMR. Even though a highly significant difference between bud burst stages was observed between seedlings from neighboring 

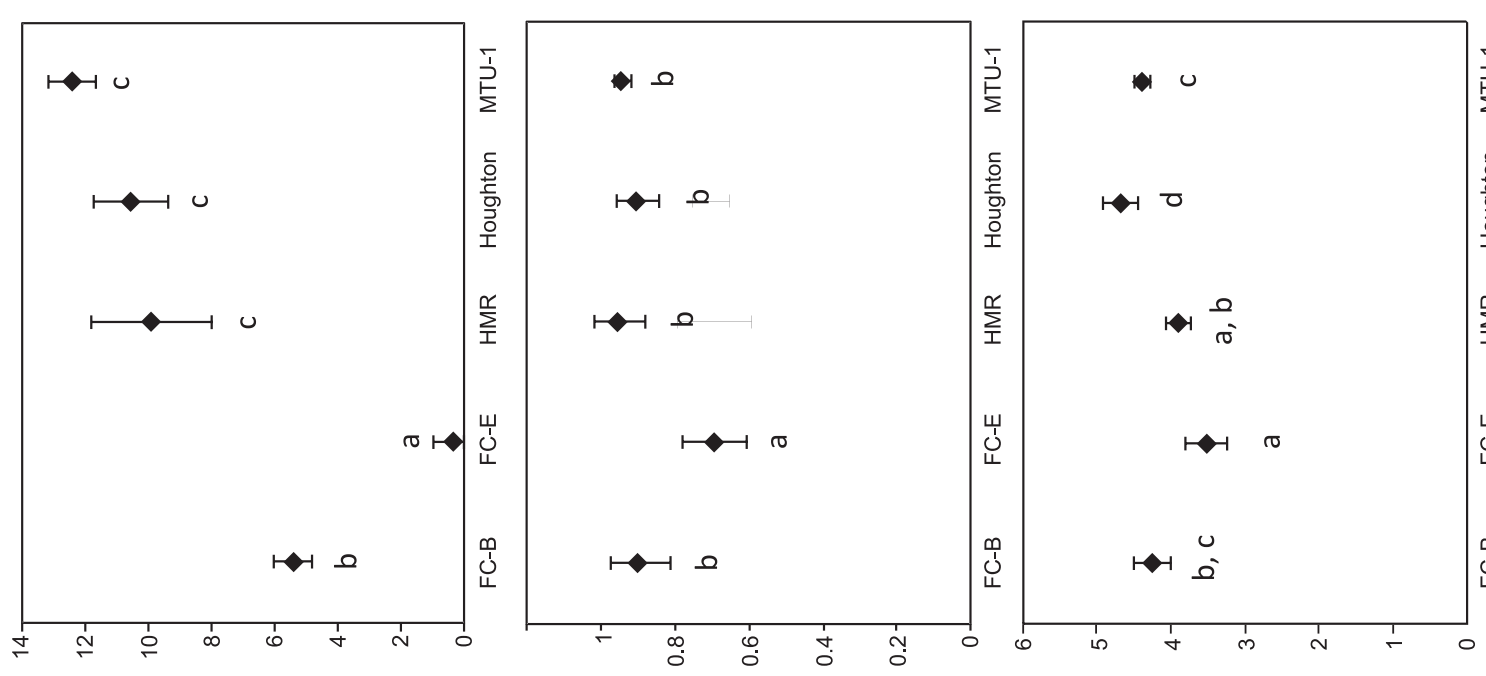

î

(ֻ)

वें के

若

离 क

范究

कै ฮี

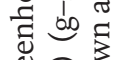

쏘 ญ

0 위 क

원

แ. ํํำ

ठั

芩苋.

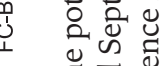

플

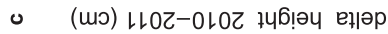

- $\quad$ ZLOZ/tL/6 ןen!nuns

- $\quad$ Zl/9Z/6 uo!̣esoloo jeə|

$\exists$ 쿵

यँّ

की
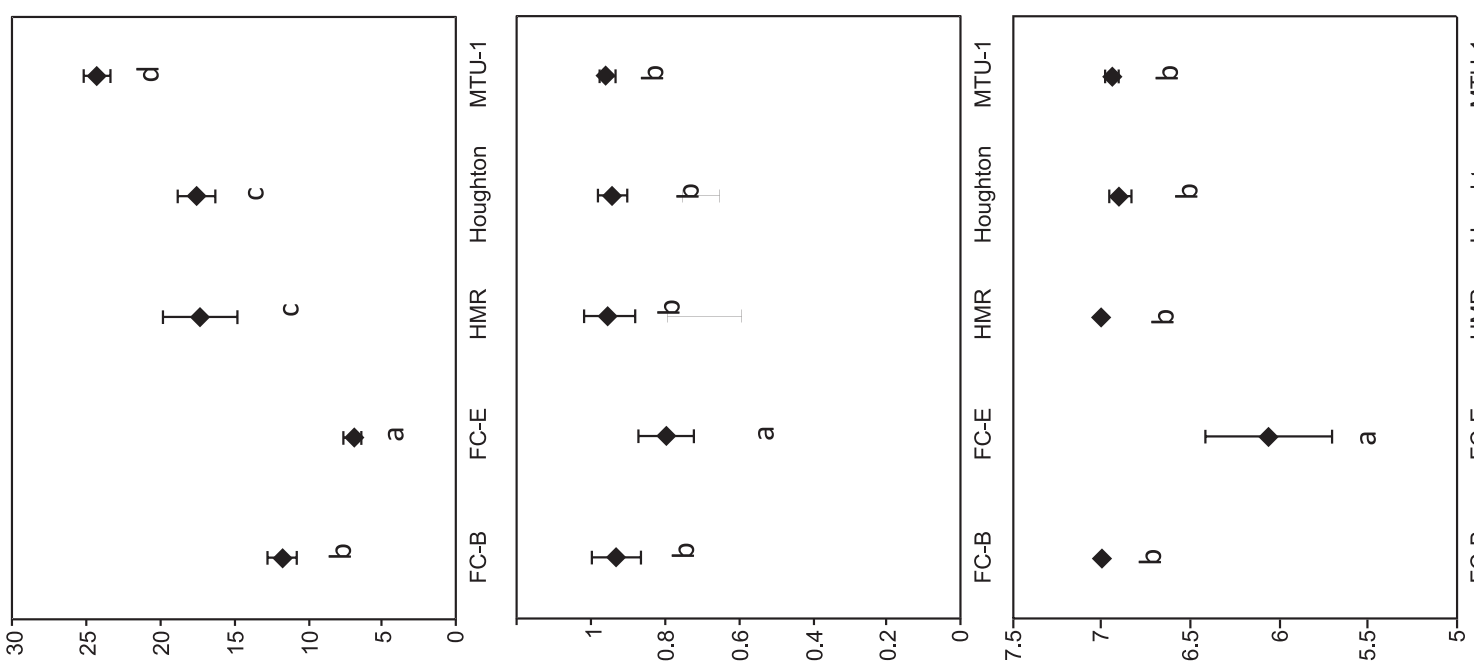

헌

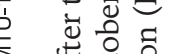

幽 원.0

तु 0

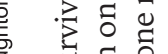

के है

के 䒕

$\sum_{1}^{1} \stackrel{0}{0} \frac{0}{0}$

드ㅇㅝㅠ

$\Xi=$ क

‡言

हี త్ర

苟茞

렁

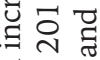

$\Omega$

(uо) $1 L / 0 L / 6-746 ! ə 4$

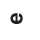

HLZ/6/9 jen!ans

$\leq$

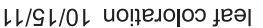

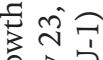

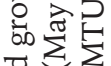

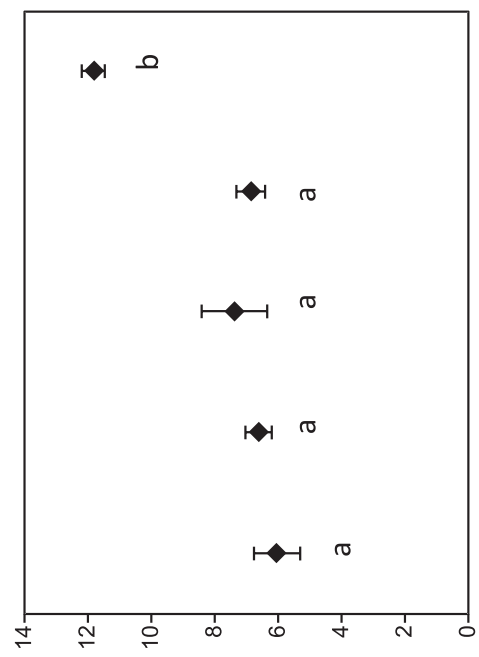

* $\quad$ (แว) $0 L / L L / 9-746$ เอบ

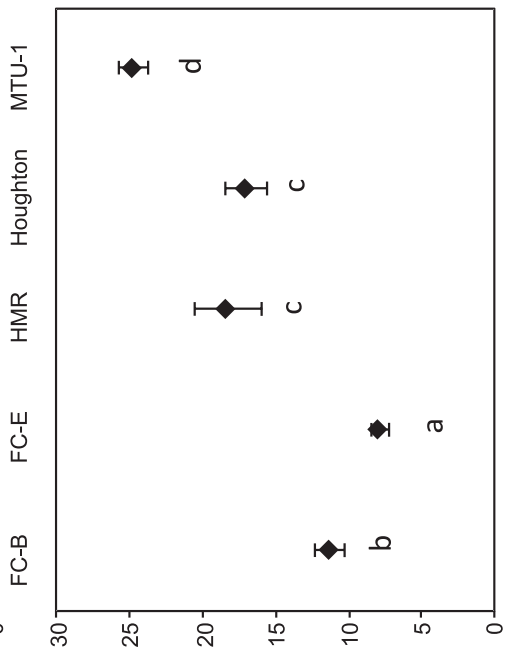

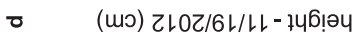

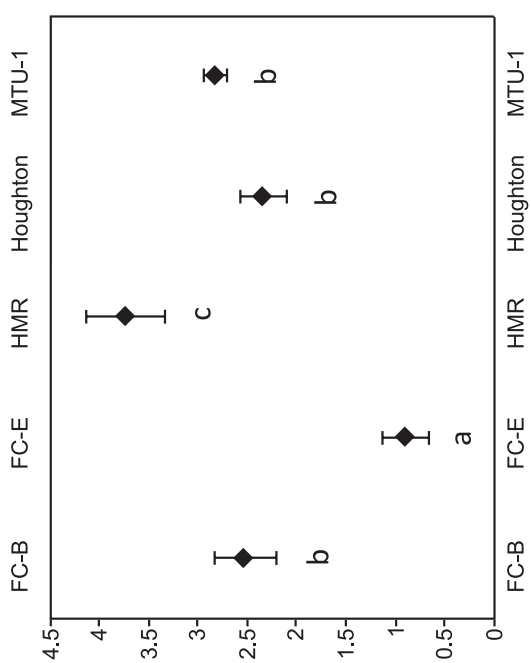

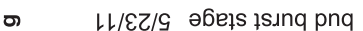

तิ

겅

구 क क

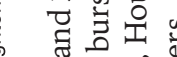

몬

유인

월

워넙

$\exists$ ㅇํㅇ

ग्. छُ

¿ั.

क्षे

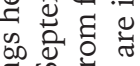

$\exists$ क

ช

क $=$ 䎡

- 엉 d 


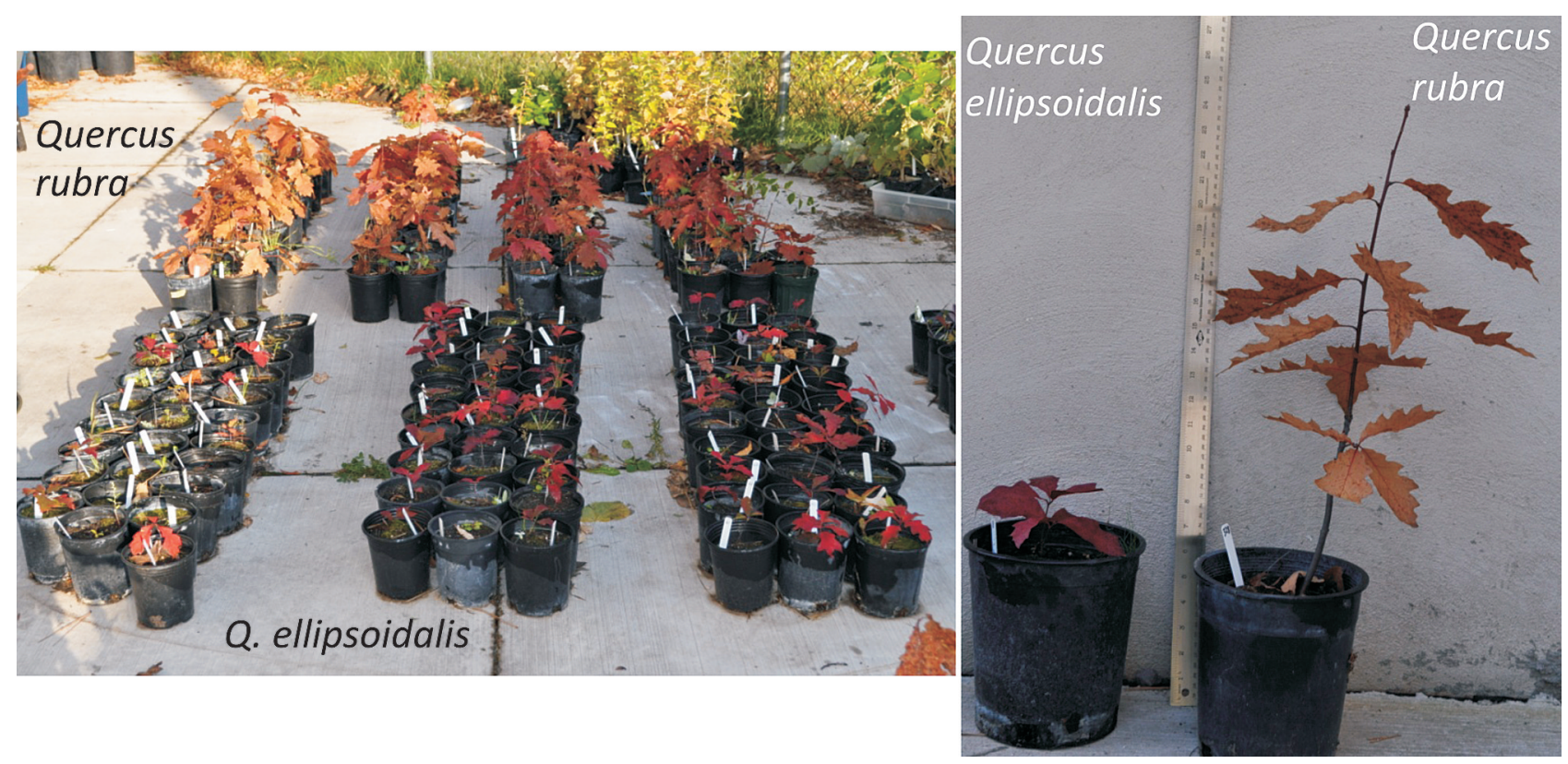

Fig. 2. Differences in seedling height and leaf coloration for Q. ellipsoidalis and randomly selected Q. rubra seedlings

$(\sim 4 \mathrm{~km}$ apart) populations FC-E (Q. ellipsoidalis) and FC-B (Q. rubra), the frequency distributions were overlapping (Fig. 3).

Also leaf fall occurred significantly later for $Q$. ellipsoidalis seedlings from FC-E than for the seedlings of the other populations indicating a shift in the growing period for both species under non-drought stress conditions. The survival rate of $79.8 \%$ until June 9, 2011 and 71.9\% until September 14, 2012 for Q. ellipsoidalis seedlings from FC-E was considerably lower than for seedlings from the $Q$. rubra populations (93.2\% to $95.7 \%$ in $2011,89.8 \%$ to $95.1 \%$ in 2012 ) (Fig. 1).

Differentiation at quantitative traits height in 2011 and 2012 (39.1\%, 40.1\%), sheight 2010-2011 (32.1\%), bud burst (24.0\%), and leaf fall in 2011 and $2012(12.5 \%, 5.4 \%)$ in the seedling generation was higher than genetic differentiation at microsatellites

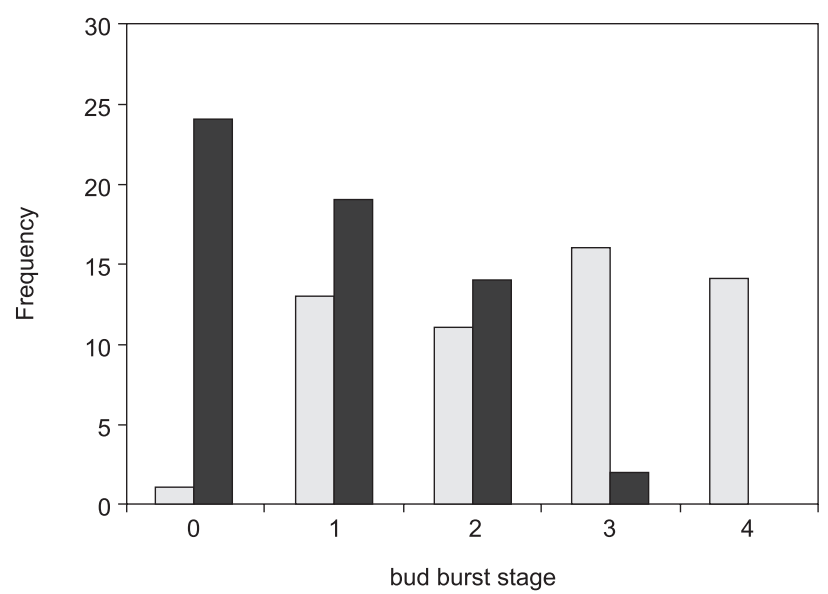

Fig. 3. Bud burst stages for Quercus rubra seedlings from stand FC-B (white bars) and for seedlings from the neighboring Q. ellipsoidalis stand FC-E (black bars) among populations within species $(1.41 \%)$ and between species (4.95\%) (Lind and Gailing 2013). The percentage of variation distributed among populations decreased to $21.0 \%$ for height $2011,23.5 \%$ for height 2012, $10.5 \%$ for $\Delta$ height $2010-2011,8.5 \%$ for bud burst, $3.4 \%$ for leaf fall 2011 and $2.7 \%$ for leaf fall 2012 when Q. ellipsoidalis population FC-E was excluded from the analysis.

\section{Discussion}

Strong and highly significant differences in growth, survival, leaf fall and bud burst between $Q$. rubra and Q. ellipsoidalis seedlings as observed in the present study in a common environment indicate that differences in these fitness-related traits are genetically controlled and contribute to pre- and post-zygotic reproductive isolation between these species. Significantly later bud burst in Q. ellipsoidalis seedlings when compared with seedlings from the Q. rubra populations including the neighboring population FC-B suggest differences in the timing of bud burst as a mechanism of pre-zygotic isolation between species. Thus, analyses in European white oaks showed a strong association between the timing of vegetative bud burst and flowering time (Chesnoiu et al. 2009; Franjic et al. 2011; Neophytou et al. 2011). Likewise, autumn senescence occurred significantly later in $Q$. ellipsoidalis than in $Q$. rubra seedling populations reflecting genetic differences in phenology traits between seedlings of both species. However, under the relatively homogenous conditions in the common garden experiment there was considerable overlap in bud burst stages for seedlings of the two species. Assessment of the timing of bud burst and flowering phenology in natural populations over several years is 
necessary to evaluate their importance for the reproductive isolation between species under natural conditions. Also selection against hybrids ("outbreeding depression") and against species in non-parental environments (post-zygotic isolation) has been suggested as a mechanism to maintain adaptive species differences in oaks (Curtu et al. 2009; Moran et al. 2012; Muller 1952; Rushton 1993; Scotti-Saintagne et al. 2004). While no evidence for selection against hybrids was found when comparing the genetic structure of adult trees and seedlings, since low numbers of hybrids were identified in the seedling (one and a half year old seedlings) and adult tree generation of $Q$. ellipsoidalis (FC-E) and Q. rubra (FC-B) (Lind and Gailing 2013), selection against hybrids in young seedlings cannot be excluded. The high survival and growth of $Q$. rubra seedlings and the very low survival and growth of $Q$. ellipsoidalis seedlings in the present study suggest a considerably lower fitness of $Q$. ellipsoidalis seedlings at early growth stages under regular water supply (no severe drought stress) and might reflect different local adaptations of the species with regard to water availability. While Q. rubra prefers mesic to well-drained soils, $Q$. ellipsoidalis as the most drought tolerant of the North American red oak species occurs on very dry and sandy sites and shows specific morphological and physiological adaptations to drought (Abrams, 1988, 1990).

Considerably higher seedling differentiation in the quantitative traits height, $\Delta$ height and bud burst among adult stands for all populations (24.0-40.1\%) and to a lesser extent after exclusion of Q. ellipsoidalis population FC-E (8.5-23.5\%) than differentiation at potentially neutral genetic markers among populations within species (1.41\%) and between species (4.95\%) (Lind and Gailing 2013) might have resulted from divergent selection on these traits since migration, genetic drift and inbreeding are expected to act on all loci and quantitative traits equally (Conner and Hartl 2004). While the direct comparison of morphological and genetic differentiation is problematic, since the additive genetic variance could not be measured directly in our experimental design, divergent selection on these traits is the most likely explanation for higher differentiation at quantitative traits than at genetic markers. Thus, epistasis and dominance would result in a $Q_{S T}$ equal or lower than $F_{S T}$ for neutral loci and a pure drift model might eventually result in higher $\mathrm{Q}_{\mathrm{ST}}$ than $\mathrm{F}_{\mathrm{ST}}$ (Whitlock 2008). While most pronounced differences in fitness traits were found between Q. ellipsoidalis seedlings on the one hand and Q. rubra seedlings on the other, significant differences found within Q. rubra indicate genetic differences among Q. rubra populations from different regions. Significant differences in $\Delta$ height were found between seedlings of $Q$. rubra population FC-B and the other Q. rubra populations, and in bud burst between seedlings of Q. rubra population HMR and the remaining Q. rubra populations.

The results of the present study suggest a genetic basis for characters related to pre- and post-zygotic isolation between $Q$. rubra and $Q$. ellipsoidalis and advocate for the assessment of these traits in reciprocal transplant experiments of seeds and natural populations across environmental gradients.

Since the strongest viability selection in forest trees like oaks is observed in the seedling stage and there is strong evidence that climate change has an effect on viability selection (Jump et al. 2006; Müller-Starck 1985), the following future analyses are necessary. (1) Genetic assignment analysis in seeds, seedlings of different age and in adult stands of both species to assess the possibility of selection against hybrids and species in non-parental environments. (2) Analysis of seedling growth, survival and vegetative bud burst of Q. rubra, Q. ellipsoidalis and hybrid seedlings in parental and non-parental environments to better understand different local adaptations of the species and hybrids to their environments (see Sork et al. 1993). Opposite trends in growth performance and survival along an environmental gradient between species habitats would confirm different local adaptations of the species. (3) Assessment of flowering phenology under field conditions in adult stands and in transplanted seedlings over several years to assess its relative importance as reproductive isolation mechanism.

\section{Acknowledgements}

I would like to thank Dr. Kerry Woods for his help in the identification of Q. rubra populations in the $\mathrm{Hu}-$ ron Mountain Wildlife Reserve. For their help in seedling measurements I would like to thank Erin Hickey, Kristina Flesher and Michael Paling. Funding for the study came from start-up funds of Michigan Technological University, the Michigan Technological University Research Excellence Fund, the USDA McIntire Stennis fund 1110031, the Huron Mountain Wildlife Foundation and the Hanes Trust.

\section{References}

Abrams M.D. 1988. Comparative water relationships of 3 successional hard wood species in central Wisconsin. Tree Physiology 4: 263-273.

Abrams M.D. 1990. Adaptations and responses to drought in Quercus species of North-America. Tree Physiology 7: 227-238.

Albert D.A., Comer P.J. 2008. Atlas of early Michigan's forests, grasslands, and wetlands. Michigan State University Press, East Lansing.

Aldrich P., Cavender-Bares J. 2011. Quercus. In: Wild crop relatives: Genomic and breeding resources, 
forest trees. Kole C. (ed). Springer, Berlin, pp. 89-129.

Arnold M.L., Martin N.H. 2010. Hybrid fitness across time and habitats. Trends in Ecology \& Evolution 25: 530-536.

Barnes B.V., Wagner Jr. W.H. 2004. Michigan Trees, A Guide to the Trees of the Great Lakes Region. The University of Michigan Press, Ann Arbor.

Chesnoiu E.N., Sofletea N., Curtu A.L., Toader A., Radu R., Enescu M. 2009. Bud burst and flowering phenology in a mixed oak forest from Eastern Romania. Annals of Forest Research 52: 199-206.

Conner J.K., Hartl D.L. 2004. A Primer of Ecological Genetics. Sinauer Associates, Sunderland.

Curtu A.L., Gailing O., Finkeldey R. 2007. Evidence for hybridization and introgression within a species-rich oak (Quercus spp.) community. BMC Evolutionary Biology 7: Article number: 218.

Curtu A.L., Gailing O., Finkeldey R. 2009. Patterns of contemporary hybridization inferred from paternity analysis in a four-oak-species forest. BMC Evolutionary Biology 9: Article Number: 284.

Dodd R.S., Afzal-Rafii Z. 2004. Selection and dispersal in a multispecies oak hybrid zone. Evolution 58: 261-269.

Fitch R. 2006. WinSTAT for Excel. The statistics add-in for Microsoft Excel. R. Fitch Software.

Franjic J., Bogdan S., Skvorc Z., Sever K., Krstonosic D. 2011. Phenological asynchronization as a restrictive factor of efficient pollination in clonal seed orchards of pedunculate oak (Quercus robur L.). Croatian Journal of Forest Engineering 32: 141-156.

Gailing O., Lind J., Lilleskov E.A. 2012. Leaf morphological and genetic differentiation between Quercus rubra L. and Q. elliposidalis E. J. Hill populations in contrasting environments. Plant Systematics and Evolution 298: 1533-1545.

Hipp A.L., Weber J.A. 2008. Taxonomy of Hill's oak (Quercus ellipsoidalis: Fagaceae): Evidence from AFLP data. Systematic Botany 33: 148-158.

Hokanson S.C., Isebrands J.G., Jensen R.J., Hancock J.F. 1993. Isozyme variation in oaks of the apostle islands in Wisconsin - genetic structure and levels of inbreeding in Quercus rubra and $Q$. ellipsoidalis (Fagaceae). American Journal of Botany 80: 1349-1357.

Inc S. 2002. SPSS 11.0 guide to data analysis. Prentice Hall Public New Jersey

Jensen R.J., Hokanson S.C., Isebrands J.G., Hancock J.F. 1993. Morphometric variation in oaks of the apostle islands in Wisconsin - evidence of hybridization between Quercus rubra and Q. ellipsoidalis (Fagaceae). American Journal of Botany 80: 1358-1366.
Jump A.S., Hunt J.M., Martinez-Izquierdo J.A., Penuelas J. 2006. Natural selection and climate change: temperature-linked spatial and temporal trends in gene frequency in Fagus sylvatica. Molecular Ecology 15: 3469-3480.

Lepais O., Gerber S. 2011. Reproductive patterns shape introgression dynamics and species succession within the European white oak complex. Evolution 65: 156-170.

Lepais O., Petit R.J., Guichoux E., Lavabre J.E., Alberto F., Kremer A., Gerber S. 2009. Species relative abundance and direction of introgression in oaks. Molecular Ecology 18: 2228-2242.

Lind J., Gailing O. 2013. Genetic structure of Quercus rubra L. and Q. ellipsoidalis E. J. Hill populations at gene-based EST-SSR and nuclear SSR markers. Tree Genetics \& Genomes. DOI 10.1007/s11295-012-0586-4.

McKay J.K., Latta R.G. 2002. Adaptive population divergence: markers, QTL and traits. Trends in Ecology \& Evolution 17: 285-291.

Moran E.V., Willis J., Clark J.S. 2012. Genetic evidence for hybridization in red oaks (Quercus Sect. Lobatae, Fagaceae). American Journal of Botany 99: 92-100.

Müller-Starck G. 1985. Genetic differences between "tolerant" and "sensitive" beeches (Fagus sylvatica L.) in an environmentally stressed adult forest stand. Silvae Genetica 34: 241-247.

Muller C. 1952. Ecological control of hybridization in Quercus: A factor in the mechanism of evolution. Evolution 6: 147-161.

Neophytou C., Aravanopoulos F.A., Fink S., Dounavi A. 2011. Interfertile oaks in an island environment. II. Limited hybridization between Quercus alnifolia Poech and Q. coccifera L. in a mixed stand. European Journal of Forest Research 130: 623-635.

Nixon K.C. 1997. Fagaceae. In: Flora of North America Editorial Committee, Morin NR (ed.) 1993. Oxford University Press. New York and Oxford. Vol. 3. Available via efloras. Accessed 21 November 2012.

Petit R.J., Bodenes C., Ducousso A., Roussel G., Kremer A. 2003. Hybridization as a mechanism of invasion in oaks. New Phytologist 161: 151-164.

Rushton B.S. 1993. Natural hybridization within the genus Quercus. Annales des Sciences Forestières 50: 73-90.

Scotti-Saintagne C., Mariette S., Porth I., Goicoechea P.G., Barreneche T., Bodenes C., Burg K., Kremer A. 2004. Genome scanning of interspecific differentiation between two closely related oak species (Quercus robur L. and Q. petraea (Matt.) Liebl.). Genetics 168: 1615-1626.

Sork V.L., Stowe K.A., Hochwender C. 1993. Evidence for local adaptation in closely adjacent 
subpopulations of northern red oak (Quercus rubra L.) expressed as resistance to leaf herbivores. American Naturalist 142: 928-936.

Spitze K. 1993. Population structure in Daphnia obtusa - quantitative genetic and allozymic variation. Genetics 135: 367-374.

Sullivan A., Lind J., McCleary T.S., Romero-Severson J., Gailing O. 2013. Development and characterization of genomic and gene-based microsatellite markers in North American red oak species. Plant Molecular Biology Reporter 31: 231-239.

Whitham T.G., Martinsen G.D., Floate K.D., Dungey H.S., Potts B.M., Keim P. 1999. Plant hybrid zones affect biodiversity: Tools for a genetic-based understanding of community structure. Ecology 80: 416-428.

Whitlock M.C. 2008. Evolutionary inference from Q(ST). Molecular Ecology 17: 1885-1896.

Woodall C.W., Oswalt C.M., Westfall J.A., Perry C.H., Nelson M.D., Finley A.O. 2009. An indicator of tree migration in forests of the eastern United States. Forest Ecology and Management 257: 1434-1444.

Zeng Y.F., Liao W.J., Petit R.J., Zhang D.Y. 2010. Exploring species limits in two closely related Chinese oaks. PLoS One 5: Article Number e15529. 